\title{
HARDY AS A MODERN NOVELIST
}

\author{
Saima Manzoor*
}

\begin{abstract}
Hardy is the last of the Victorian and one of the most popular novelists of England. $\mathrm{He}$, being an author of unique endowments, was not much esteemed in his life time. Hardy became the victim of stereotypical criticism and was badly ostracized by the ecclesiastical circles and the critics of his time as they merely focused on the depressing features of his fiction. This paper intends to reveal certain aspects of his work which remained neglected for a long time. The present study is designed to focus on those characteristics of his work which win the title of a modern novelist for him. Hardy was quite conscious of the shifting environment around him at the vogue of industrialization that left profound marks on his meditative temperament. His depiction of the $19^{\text {th }}$ century scenario is dominated with clash and collision between innovation and tradition. His art deals with twofold aspects of modernity exposing the sanguine and gloomy consequences of modernity. Owing to such an approach of the writer he is regarded as a social realist and one of the earliest of the modern novelists. Hardy poignantly observes the pathetic condition of the labourers, on one hand, and the modern mechanical advancements, one the other, which were of little benefit for the common man in society. The current study is designed to focus upon his approach to the modern developments in the broad context of social and political changes. Hardy is a modern novelist as he concentrates on the current issues such as gender, class, social and psychological disorders, etc. He is a supporter of class and female liberation.
\end{abstract}

Keywords: industrialization, modernization, old order, new order, class conflict, gender, community

\section{Introduction}

The present assessment discovers that Hardy's novels highlight the dual role of modern developments. His attitude towards modern civilization is analyzed with reference to his major novels. The phrase modern civilization, with reference to Hardy's novels, means a phase of social advancement of the recent or latest times. Modernization, an ever continuous process, had an origination and according to critics it began in the Victorian England. The prominent Victorians, especially the men of letters, were regarded as the earliest of the moderns. As a worldwide phenomenon modernization alters the primeval social setup into the latest one.

While focusing upon the burning issues of the late nineteenth century Victorian England, such as, the latest developments, the condition of the labourers, deficient industrial advancement in the rustic area, and matters of class and gender, this article also traces the signs of modernity in Hardy's fiction. In the course of this research paper Hardy's novels, especially, his approach towards modern civilization

\footnotetext{
* Saima Manzoor, Ph.D., Lecturer, Department of English Literature, University of Balochistan, Quetta
} 
is evaluated in the light of the comments made by various critics. Hardy's novels are regarded as visual novels as he, in them, vividly depicts the social evils of his time. The present study investigates Hardy's novels from a new perspective that being a socialist his attitude towards modern civilization, class distinction and gender issue is tinged with clash and conflict. The study explores Hardy's attitude towards modern civilization which is marked with duality forming the mainstream of his art. According to Anita Sandlin, "These conflicting perspectives reflect the internal ambiguities of a gifted man torn between wanting to maintain the conservative comfort of the Victorian era while yearning for the more equitable freedom of the Modern era.'(Sandlin, 2011,p.1). This research evaluates that on one hand he approves the modern mechanical advancements in all the arenas of life and on the other; he disapproves them if they fail to improve the condition of the common man. Hardy like other Victorian writers was mainly concerned with the, “...contemporary plight of the newly industrialized working class..." (Walder.2001, p.381). Hardy infact wanted to admonish that the working class should get the benefit they deserve from the modern industry. The aim and objective of the study is to explore the social issues which develop awareness that inequality, exploitation and injustice between the classes and genders can produce hostile atmosphere. Hardy is a modern writer and in his novels he expressed his abhorrence against the conservative and orthodox customs of the Victorian society which were harmful for individual aspiration. According to David Cecil, "Intellectually, Hardy was a man of the new age- a socalled advanced thinker, in open rebellion against traditional orthodox views about religion, sex and so on- and he used his novels to preach these heretical opinions."(Cecil, 1969, p.39).

Hardy was a keen observer of the changes happening around in the social setup. While standing on the threshold of the nineteenth century. Hardy along with him made the readers to witness the scenario full of clash and conflict between the old and the new order. Barbara Hardy rightly comments that Hardy is, "....a great artist who challenges our conception of the Victorian and the modern ..." (Hardy, 2000, p.4). A general analysis of Hardy's novels, especially, The Mayor of Casterbridge (1965) provides relevant evidence about the disparity between ancient and modern. Henchard with his inflexibility embodies old order of backwardness; on the other hand, Farfrae embodies new order. The former is overpowered by the later. Infact Henchard's conquest is the downfall of the old order whereas Farfrae's victory symbolizes the triumph of modernization. In the course of the story we come to know that Hardy mournfully reveals that innovation and invention will triumph over convention and tradition. The never-ending strife between old and new is presented through the protagonist and antagonist and their adoption of conventional and modern ways to trade. Joseph Carroll highlights that, Henchard comes into sharp conflict...with Farfrae..." (Carroll, 2010, p.175). The rivalry between the characters infact is the friction between the old and the new and their encounter indicates the termination of the prior owing to internal faults.

Hardy's novels mainly deal with invention and ennui and the major issues raised by his fiction are his focus upon mechanical advancements, social and psychosomatic turmoil. With reference to these features of Hardy's novels we may quote Jesse Matz whose work provides an evidence of the presence of the elements of modernity in Hardy's novels. Jesse Matz states in his book The Modern Novel A Short Introduction (2004) that, “.... what it means for a novel to be modern. It means facing the problems and possibilities of modernity-the technological wonders, the 
social disorder, the psychological mysteries, the pattern of change- and making them fiction's main challenge and inspiration.” (Matz, 2004,p.13).

\section{Review}

The conventional criticism highlights the negative aspects of Hardy's art whereas the present research digresses from the typical critical approaches and it frees him from the stereotypical criticism which restricted his approach to pessimism, fatalism, agnosticism, atheism, etc. Hardy's novels command concentration and appreciation on various accounts. He made his novels a powerful instrument to modulate the social framework. The purpose of this paper is, also, to explore those domains of Hardy's work which open up new avenues of thought. Hardy's main concentration is common man and his major novels trace the impact of latest advancements on man and on rest of the social order. Hardy, while following the modern trend, also portrays the importance of community in the life of an individual. In The Mayor of Casterbridge (1965) Michael Henchard, a hay cutter, rises up to the position of the mayor of the town. He is respected by the whole community on the account of his achievement. Later Henchard, as Norman Page remarks, is, "... rejected by the community that had formerly respected and honoured him."(Page, 2001, p.101). Henchard is punished on account of his past misdoing. Hardy visualizes that the lack of cooperation among the masses is the cause of their destruction. Henchard being a human committed a sin .He had an illegal relationship with a woman, namely, Lucetta. and he always regretted it. When the village folks come to know about Henchard's illicit relationship with Lucetta, they arrange a "Skimmington ride" which is, "... a traditional and noisy demonstration of communal disapproval of immorality..." (Page, 2001, p.101). Henchard is not forgiven by the village community. Hardy holds community responsible for the fall of an isolated individual. It is the common dilemma of the modern world that despite all the progress humanity as a whole suffers from a sense of isolation and deprivation. Hardy here condemns the orthodox society which is vindictive and not ready to exonerate an individual. Ultimately, Henchard dies while suffering from the sense of guilt and isolation. Destruction of the individual talent is but the result of hostile community.

This paper also explores certain features of Hardy's art which reveal that the changes around him were ironically enhancing the problems of the simple- minded people of his native land at the fall of old values and tradition. Hardy, generally, is viewed as pessimist, fatalist, agnostic, atheist, nihilist, determinist by the critics. His view of life also includes meliorism, realism, and secularism. As he advanced in years, his brooding temperament led him to develop a systematized philosophy of life. Hardy while mainly concentrating upon pastoral affairs often allows his vision to stray in chaos and confusion. The severe criticism on his work led him to explain that his novels are rather impressions than arguments and his fiction is the direct outcome of the impressions he received from the material world. Hardy was a sensitive person who observed the changing environment around. Generally he is considered as a writer of pessimistic approach towards nature and human nature. According to Dorothy Mermin and Herbert Tucker, "His grim vision of nature and human life suited modernist sensibility ..." (Mermin, \& Tucker, 2002, p.79). The modern developments in the nineteenth century made the people aware about the changes in their traditional life style. 
Hardy is a modern writer but the critics have generally projected him as a pessimist. The present research highlights his attitude towards modern developments in the nineteenth century. He, in his work, keenly observes the positive and the negative impacts of the modern developments on man and society. He mainly concentrates upon the rural areas where comparatively the process of modernization was slow. In the age of invention and discovery the indigenous people, for their survival, had to struggle hard. Critics blame Hardy as a tragic writer as his hero fails to achieve the goal and towards the end of the story meets his tragic doom. The conventional romances usually project a hero who takes incentive and his rebellion remains fruitful. The present investigation proves that Hardy is a realist and his tales are in disagreement with the conventional stories. His novels project a clash between individuals and community. Through the failure of an isolated individual he stresses upon the significance of community in the life of individual. He projects the drawbacks of social system where individual alone despite great struggle remains helpless. Hardy through individual failure hints towards faulty social structure which is not supportive. He blames the social setup for the defeat of his characters. He resented the artificial structure of the society. He was quite aware of the fact that this faulty system can be harmful to nature and it could also restrain high aspirations and endeavors. So he propounds the theory, implementation of which requires the alleviation of old order, giving way to new one.

The major theme of all Hardy's novels is man's futile struggle against forces of evil, death and destruction. Hardy was hyper sensitive and his attitude to life was melancholic. Such an attitude was the result of the environment around him which was full of suffering. In this regard David Cecil comments that, "This disposition to a melancholy view was confirmed and increased by the age in which he lived. It was a disturbing age for a sensitive mind; for it was an age of transition. The Industrial Revolution was in the process of destroying the old agricultural England; the population was shifting; the old ties which have united the small communities of the past were breaking bit by bit. Along with the disintegration of the old social and economic structure went a disintegration of ideas." (Cecil, 1969, p.20).

The current study on Hardy, deviating from conventional criticism, endeavors to develop a reversal of feeling with reference to his work. Hardy, being a progressive minded person, remained vulnerable to negative criticism and condemnation during his life time as the secondary issues such as role of fate and chance became the focus of the critics whereas the issues of prime importance which are mentioned in this current research remained neglected for a considerable time. Hardy is blamed as a pessimist as he was writing social tragedy showing catastrophic end of the central characters. He was quite conscious of the transformation in all the phases of life around him which he observed gravely and critically. The modern mechanical advancements, class, gender and social issues gripped his attention throughout. Unluckily, his fiction lacks evaluation from these perspectives. The nineteenth century was a period when England passed through the phase of modernization which was quite swift in the urban areas where as in the rural parts of the country the people were still suffering from unemployment, malnourishment and deprivation. Enhancement of social awareness amongst the indigenous people of his land was at the top of his agenda. He wanted to provoke the social orders to think sympathetically for the downtrodden. His stories revolve around the exploited and the exploiter and they also project class and gender conflicts promoting female and class liberation. 


\section{Discussion and argument}

The present research evaluates Hardy's novels from diverse standpoint concentrating on the burning issues such as modern developments, gender conflicts, social stratification and the transformation of society from ancient to modern. His themes rotate around industrial developments, migration to urban areas and modern inventions. Hardy, having a complex and vital attitude towards modernization, portrays the positive and the negative aspects of modernity with reference to individuals and rural community. In this regard Hardy's novel The Return of the Native (1964) can provide relevant evidence as far as dual aspects of modernity are concerned. Eustacia Vye, having a passion to enjoy the town life in Paris, is weary of the dullness of Edgon Heath. To critics it is under the spirit of modernism that she earnestly wants to get rid of Edgon Heath, but in the same novel Clym, a diamond dealer in Paris, is ironically tired of the artificial modern town life. He ultimately resolves to reside in Edgon Heath. Clym's return to Heath is in great benefit for the natives of his land as he on his return, intends to educate the illiterate rustics. Both Eustacia and Clym symbolize a clash of interests, attraction for and repulsion against modernism. Through Clym's return Hardy indirectly highlights the need and importance of education for the countryside.

Hardy is blamed for his pessimism and cynicism .According to Percy Wilson, "Most serious modern novels are marked by uncertainty and pessimism may be cynicism also." (Wilson, 1968, p.11). Hardy's art resides on the projection of the miserable condition of the countryside. He is an egalitarian and in his novels disapproves social stratification that affects the individuals. In his novels we find a conflict between class and individuals and this element links his novels with the modern fiction. According to George Lukacs, "the new relationship between individual and society, between individual and class, creates a new situation for the modern novel."(Lukacs, 1969, p.174). Hardy rejects class distinction and approves classless society .This feature of his work links him with socialism which was a modern doctrine or system in the nineteenth century. He through the striving individuals of his novels disapproves class distinction as it destroys individual talent, for example, Tess and Jude suffer badly because of their low social status. Hardy wanted to renovate the artificial social structure where individuals are victimized due to their lower social class.

Though critics generally blame Hardy as hyper sensitive and melancholic and it is true to some extent as the shifting environment around him blurred his vision but, on the other hand ,his stories are drenched with moral lessons and his heroes are often his own reflection in the portrayal of their specific sentiments and feelings. Here we may quote Micheal Henchard's character who states in his will that nobody should attend his funeral or remember him after his death. Though, to critics, Henchard is the victim of Hardy's fatalism but his will is marked with sarcasm as it is an evidence of his complete isolation from the rest of the social order. The theme of personal isolation is of extreme importance for modern writers such as Hardy. The depiction of detachment between the individual and the community is one of the main themes of his novels.

Hardy belonging to Victorian society could not escape from the current influences of his time such as Marxism, Darwinism, and Malthusianism. As a modern writer his focus is the current issues of society, especially, those having harmful effects 
within social order including social and psychological problems and according to Percy Wilson , “...the vast range of ideas, psychological, social ... that are raised by modern fiction ..." (Wilson, 1968, p.14).

Hardy, in his work, sketches the poor condition of the labourers. He vividly shows the sufferings of the lower classes. This ability to put himself at the place of sufferer itself is a modern element called empathy. He portrays the miserable lives of rustics with an empathetic approach and the reasons of their sufferings. It is because of their lack of education, prompt increase of population in the poverty stricken labouring class, etc. The modern technological advancements such as railway and modern machines are often mentioned by Hardy in his novels. His revolutionary characters strive to improve their conditions and they often reject to follow the conventional path. Jude has an ambition to acquire the highest degree. The novel reveals that material degradation, social distress and instability have negative impact, not only, on his aspirations and fancies but also on the fancies of so many others who are struggling to achieve their goals. Jude, tired and exhausted from material world, realizes that human beings are handicapped at the hands of circumstances. Jeremy Hawthorn states about Hardy's Jude The Obscure (1972) that, “...it undeniably involves and attack upon certain social conventions which are seen as repressive and although in a sense it clearly 'calls for' a change in society so that ...working people have greater opportunities for self- development and for education ..." (Hawthorn, 2005,p.196) .

The Victorian writers, in their fiction, focus on the wretched condition of masses and role of education for the improvement of their lives. Hardy also stresses upon the significance of education for the rustics, especially, for the women of the labouring class. In Tess of the D'Urbervilles (1891) Tess suffers to resolve the financial problem of her family. She becomes a toy in the hands of the cruel male dominant society because of her uneducated status. Through her catastrophic end Hardy hints that education is a safeguard for women against exploitation and oppression. Hardy realizes that the rustics would waste themselves without education or respect while working on the fields. Read and Oselin revealed that education came, "...to be viewed as a means of economic mobility for the family..." (Read and Oselin, 2008, p.310). Michael Henchard, In The Mayor of Casterbridge (1965), is presented as an uneducated man who strives to improve himself. He admires those who are educated and sophisticated. It is because of these merits that Henchard is attracted towards Farfrae, the Scotsman, who later becomes Henchard's rival in business and in love. Farfrae wins Henchard's beloved Lucetta as he is better educated and cultivated. Henchard, too, despises Susan, his abandoned wife, as she lacks intellectual depth. Hardy also highlights the importance of education on the part of women. Henchard's stepdaughter, Elizabeth Jane, faces his repulsion because of her course manners. This causes her to educate and improve herself and later because of this she feels that Henchard is a little softened towards her. Elizabeth Jane presented as a promising young woman who has lust for knowledge. Through Elizabeth Jane's character Hardy expresses his affection for his female characters and also his resentment at their ignorance.

Hardy as a modern novelist concentrates upon the matters of gender. The Victorian society assigned to women the role of old maids and women were considered to live for family including children and husband. It was believed that suffering on the part of women enhanced their beauty. The Victorians appreciated the self sacrificing 
women. Hardy in his fiction revolted against such an attitude of the Victorians with reference to women. In this regard Molly Lefebure states that, "Hardy sagely exploited the accepted sexual climate of his day; women were to be treated as objects, either to be ground underfoot, or placed mute and motionless, on a pedestal. They were not considered living realities in the sense that men were."(Lefebure, 1997, p.52-53). In 1890s England's political and social scenario was haunted by socialism and along with it there also emerged the concept of new woman. As a result the women were attracted towards professions and university education. The nineteenth century English society gave great importance to the position of women Dorothy Mermin and Herbert Tucker state that, "The "woman question"- that is what women's status in society should be- perplexed the nineteenth century...". (Mermin \& Tucker,2002, p.81). In the nineteenth century the society was greatly concerned about the position of women in society. Generally the women were quite passionate to improve their status. Bathsheba Everdence and Sue Bridehead, the heroines of Hardy's Far From the Madding Crowd (1969) and Jude the Obscure (1972), are modern women who want to perform their particular role in society. Sue Bridehead attracted the critics and readers because of her intellectualism. Her character symbolizes rationalism and restlessness and because of these merits she is labeled as the new woman of the period. Her character is a symbol of class emancipation. Hardy's heroines are the modern women who perform their roles in society. In Far From the Madding Crowd (1969) Bathsheba Everdence, who is quite renowned in the rural community for her talents in farming, symbolizes, "...the social rise which had advance her from a cottage to a large house and fields."(Hardy, 1969,p.96). Hardy takes especial interest in his female characters. To share the burden in society, he incites them to perform their roles with responsibility. Bathsheba Everdence appears at Corn Exchange on a market day and it marks the emergence of women in various fields of life. Hardy admiringly narrates that, "Among these heavy yeomen a feminine figure glided, the single one of her sex that the room contained. She was prettily and daintily dressed ...It had required a little determination-far more than she had at first imagined to take up a position here..." (Hardy, 1969, p.104-1056).

The nineteenth century agricultural England, under the effect of industrialization, was passing through great changes and the scientific discoveries and inventions improved the condition of society. English workingmen became quite hopeful about the improvement with reference to their condition. But the rich industrialists and capitalists exploited their labour. They were becoming richer at the cost of poor whose condition continued to deteriorate resulting in social distress. In Hardy's fiction class conflict dominates and, "Class has central role in Hardy's works..." (Nazir, 2013,p.192). The capitalist class is targeted in Hardy's novels where he highlights the impact of modern civilization and the poor condition of labourers. He observes the process of Industrial Revolution and its influence on man in particular and on society in general. In Tess of the D'Urbervilles (1891) he shows that if working on fields is difficult then it is not equally easy to operate the machine continuously. Tess, working on the machine like a machine, gets exhausted and ultimately she ,Hardy quotes in Tess of the D'Urbervilles, “.... suddenly flagged and sank down upon the heap of wheat-ear at her feet”. (Hardy, 1891, p.372). The negative aspect of the mechanization is that the machine is not introduced to cut down the working hours of the labourers rather it is for the benefit of the farmers to raise their profits. 
Under the effect of industrialization migration towards cities occurred and the number of factories and machines was multiplied. This was an era of the invention of steam engine and because of this modern invention traveling became more enjoyable and less time consuming. The railway connectivity was infact an expansion of the Industrial Revolution to the other parts of the world. With reference to the establishment of railway Herzstein remarks that, "The railroads, therefore, can be regarded as the driving force behind the expansion of the Industrial Revolution.”(Herzstein, 1975,p.492). In Hardy's novels we find railway playing an important role. In A Pair of Blue Eyes (1985), Tess of the D'Urbervilles (1891) and Jude the Obscure (1972) we find multiple references to that latest mode of traveling which was the gift of industrialization.

Hardy's approach towards modernity is not free of clash and conflict and His novel The Mayor of Casterbridge (1965) is an evidence of the decline of old order and while going through the novel we mournfully behold that when the orthodox way of life collide with the new one, the former is defeated due to inner defects. Henchard relies upon traditional ways whereas Farfrae, an agriculturist of new kind, is ever ready to adopt the new modes. Henchard , churchwarden and the mayor of the town, is trained as a hay-cutter and he deals with hay and corn. Henchard expresses his anxiety about his grown wheat before Farfrae who restores his bad crop with the help of latest technology. According to Sandlin, "The Modern era ushered in new ideas of technology and industry along with new perspectives on personal relationships.' (Sandlin, 2011, p.10). Henchard offers Farfrae to work with him as his business partner and this relationship is formed because, unfortunately, Hanchard is quite ignorant of the modern technology. Whereas Farfrae is a man who is well equipped with the latest knowledge and can operate the modern machinery. Farfrae's thirst for knowledge and interest in new technology results in Henchard's dependency upon him . Henchard is impressed by Farfrae's knowledge of the latest technology and his bad wheat is quite restored by Farfrae with the help of the latest machine. The story hints that the "Human Knowledge is broadening everyday, resulting in newer and more efficient technologies to meet the present-day demands. It has given industry a newer face and better form in terms of both quality and quantity."(Thakur, 2006, p.142). Henchard is destined to be destroyed with his old ways. In the course of the novel Henchard makes fun of the machine, namely, horse-drill .He remains dubious about its utility and function. Whereas, Farfrae handles the machine skillfully and is determined to improve the sowing methods with it. Besides, he is also fond of traveling through the world. According to Merryn Williams Farfrae is one of Hardy's heroes who, “...refuse to let themselves be extinguished by circumstances, and who bring new skills and intelligence to the community. His process for restoring bad grain, his modern methods of managements and the horse-drill which he pioneers to 'revolutionize sowing' are all positive contributions to the towns' agricultural life.”(Williams, 1974,p.150).

Hardy's novel The Woodlanders (1949) contains the positive aspects of modernity where Dr. Fitzpiers, married to Grace Melbury, enjoys an illicit affair with Mrs. Charmond. As a result Grace wants to get legal remedy in the form of divorce to put an end to the unhappy marriage. Fred Beaucock, who has served as clerk under a lawyer, informs Mr. Melbury about the new divorce laws which are taken as a new legal remedy for the unhappy matrimonial affairs. Fred Beaucock informs Mr. Melbury that, "under the new law, Sir A new court was established last year, and under the new statue...unmarrying is as easy as marrying."(Hardy,1949,p.326). 
Hardy expresses Grace's relief in such vivid words that, "the new law' was to her a mysterious, beneficent, godlike entity, lately descended upon earth, that would make her as she once had been without trouble or annoyance."(Hardy, 1949, p.335). Later, Mr. Melbury is informed by Mr. Beaucock about their failure to seek divorce as Fitzpiers' conduct has not been proved cruel enough to cancel the bond. Ultimately, Grace is destined to be Fitzpiers' wife till the end. Hardy condemns the social setup which restricts individual freedom to live the life happily. Especially he highlights that women face great opposition while seeking divorce either by society or by courts. With reference to such an orthodox attitude of society towards women Nathalie Bernard Maugiron states that, "In practice, women face a huge number of obstacles in the implementation of the rights to which they are entitled in divorce matters, whether before courts or in society." (Maugiron, 2008, p.62).

Hardy's work shows evident signs of Freudism and, “...the study of the mind in the late nineteenth century became the province of the new scientific discipline and psychology itself was conceived of as an empirical science, grounded in a materialist study of the brain and its physiology."(Guy,1998,p.202). In The Woodlanders (1949) the promising doctor, Fitzpiers, wants to enhance his knowledge about human brain. To fulfill his motive he motivates Gammer Oliver, an old woman, to allow him to conduct research work on her skull after her death. Infact, the doctor's desire to enhance his knowledge about neurology is in accordance with the period where quest was in vogue in all the fields.

Hardy's novels while highlighting the positive role of modern developments, also, hint at the diverse effects of modernity. In the nineteenth century population explosion, a result of modern developments in the fields of science and medicine became a challenging issue. It alarmed the society and caught the attention of the writers, including, Hardy who knew that rapid increase of population would produce catastrophic ends. In Jude the Obscure (1972) Jude's son, Father Time, finds that his stepmother Sue could not provide habitation to the off springs in Jude's absence. Father Time is informed by Sue about another baby who is likely to be born soon. This multiplied his depression and he kills his little brother and sisters and puts an end to his own life leaving the statement behind, "Done because we are too many."(Hardy, 1972, p.347). Jude later informs Sue about the doctor's opinion that such boys are the production of modernity and they foresee all the horrors of existence before they get mature. In the novel Jude further comments about Father Time before Sue in the following words that, 'It was in his nature to do it. The doctor says there are such boys springing up amongst us-boys of a sort unknown in the last generation -the outcome of new views of life. They seem to see all its terrors before they are old enough to have staying power to resist them. He says it is the beginning of the coming universal wish not to live.'(Hardy, 1972, p.348). With reference to this particular scene where Father Time performs the gruesome act of butchery we come to know that Hardy is quite conscious of the heedless growth of population. Here we find the influence of the nineteenth century philosopher and intellectual T. R. Malthus, upon Hardy's mind. T. R. Malthus was a great Victorian figure and founder of the theory of Malthusianism. Who believed that rapid increase of population would cause famine. In this sense Hardy, like him, is in favor of family limitation and it is also a modern conception.

\section{Conclusion}


The present investigation tends to produce a reversal of feeling for the writer and reveals another Thomas Hardy who is quite different from that of his own time. The present research has rejected the old criticism that labels Hardy as merely a writer of pessimistic temperament. The current study has liberated him from the stereotypical criticism as it streamlines new avenues of thought with reference to Hardy's work. Hardy, a modern writer, highlights the role of modern developments in the nineteenth century. He keenly observed the English society shifting from pre industrial to industrial one. His work provides the positive and the negative impacts of the modern developments on the social order. He sympathizes with the rural areas where the process of modernization was slow and the rustics had to strive hard to fulfill the basic requirements of life. His work hints towards the role of community in making or marring the life of an individual. The theme of individual isolation is also the focus of his work.

\section{References}

Carroll, Joseph. (2010).Style: Quantifying Tonal Analysis in The Mayor of Casterbridge. Volume 44, Nos.1\&2,Spring/Summer.p175.

Cecil, David. (1969). Hardy The Novelist. An Essay in Criticism. London: Constable and Company 10-12 Orange Street, W. C. Z. p.39,20.

Guy, Josephine M.(1998). The Victorian Age An Anthology of sources and document. London: Routledge. p.202.

Hardy,Barbara.(2000)Thomas Hardy Imagining Imagination Hardy's Poetry and Fiction. London: The Athlone Press.p.4.

Hardy, Thomas.( 1891). Tess Of The D'urbervilles. London: Penguin Books Ltd. p.372.

Hardy, Thomas. (1949). The Woodlanders. London: Macmillan \& Co., Ltd. p.326335 .

Hardy, Thomas.(1965). The Mayor of Casterbridge. New York: Airmont Publishing Company, Inc. p.255.

Hardy, Thomas. (1969). Far From The Madding Crowd. London: Co Ltd.p.95-104105-124.

Hardy, Thomas.(1972). Jude the Obscure. London: Macmillan St Martin's Press. P.347-348.

Herzstein, Robert Edwin.(1975). Western Civilization. USA: Houghton Mifflin Company. p. 492.

Hawthorn, Jeremy. (2005) Studying the Novel. New York: Oxford University Press Inc p.196.

Lefebure, Molly (1997). Thomas Hardy's World. The Life, times and works of the Great Novelist and Poet. Spain: Charlton Books Ltd. p.52-53. 
Lukacs, George. (1969). The Historical Novel. A Peregrine Book. England: Merlin Press. p.174.

Matz, Jesse. (2004). The Modern Novel A Short Introduction. UK: Blackwell Publishing Company. p.13.

Maugiron ,Nathalie Bernard and Durpret, Baudouin..(2008) "Breaking up The Family: Divorce in Egyptian Law and Practice". Journal of Women of the Middle East and the Islamic World. (6). p.62.

Mermin, Dorothy and Tucker, Herbert.(2002) Victorian Literature 1830-1900. Philadelphia: Hercourt College Publishers. p.79,81.

Nazir, Farkhanda. (2013)Impact of Class on life-A Marxist Study of Thomas Hardy's Novel Tess of the D'Urbervilles . Language in India. www.languageindia.comISSN1930-2940.p.192.

Page, Norman . (2001). Thomas Hardy The Novels. London: Palgrave.p.101,101.

Ray, Mohit K and Kundu, Rama. (2005) Studies in Women Writers in English. Vol.IV. New Delhi: Atlantic Publishers and Distributors.p.177.

Read, Jen'nan Ghazal and Oselin, Sharon. (2008) “Gender And The EducationEmployment Paradox in Ethnic And Religious Contexts: The Case of Arab Americans". American Sociological Review.No-2. Vol. 73 April .p. 310.

Sandlin,Anita.(2011). "Fear and Fascination :A Study of Thomas Hardy and the New Woman'. MA Thesis .Georgia Southern University. Electronic Theses \& Desertations. Papers.p.1,10.

Thakur, Indu Shekar. (2006). Industrial Biotechnology Problems And Remedies. New Delhi: Krishan Makhijani for I.K. International Pvt. Ltd. p.142.

Walder,Dennis . ( 2001) ed. The Nineteenth-Century Novel Identities. USA: Routledge. p.381.

Williams, Merryn.(1974) Thomas Hardy And Rural England. London:The Macmillan Press Ltd.p. 150.

Wilson, Percy.(1968)."Introduction": Modern Novelists selected reading. ed. by PercyWilson. London: Billing \& Sons Ltd. p.11,14. 